\title{
Seasonal Susceptibility of Grapevine Pruning Wounds and Cane Colonization in Catalonia, Spain Following Artificial Infection with Diplodia seriata and Phaeomoniella chlamydospora
}

\author{
Georgina Elena and Jordi Luque, Department of Plant Pathology, IRTA Cabrils, 08348 Cabrils, Barcelona, Spain
}

\begin{abstract}
Elena, G., and Luque, J. 2016. Seasonal susceptibility of grapevine pruning wounds and cane colonization in Catalonia, Spain following artificial infection with Diplodia seriata and Phaeomoniella chlamydospora. Plant Dis. 100:1651-1659.

Diplodia seriata and Phaeomoniella chlamydospora are two fungal pathogens associated with grapevine trunk diseases worldwide. This study aimed to evaluate the period during which grapevine pruning wounds remain susceptible to fungal infection and to describe the colonization of canes artificially inoculated with these pathogens. In the first experiment, pruning wounds made in either fall or winter were separately inoculated with each pathogen at different times after pruning. Wound susceptibility to both pathogens decreased as the period between pruning and inoculation increased, from high percentages recorded in the first inoculation round (D. seriata, $97.5 \%$ and P. chlamydospora, $75 \%$ ) down to approximately

$10 \% 12$ weeks after pruning. Pruning wounds remained more susceptible to $D$. seriata after a late pruning in winter whereas no overall seasonal changes in wound susceptibility were detected for $P$. chlamydospora. In the second experiment, canes were pruned by leaving two different lengths between the top node and the pruning wound before inoculations. Pathogens were recovered at different incubation periods and from different sites along the canes to estimate fungal cane colonization. A longer pruned internode made cane colonization by $P$. chlamydospora difficult, as indicated by fungal recoveries lower than $10 \%$ at the lowest recovery site, whereas D. seriata was less inhibited.
\end{abstract}

Botryosphaeria dieback, esca, and Eutypa dieback are the most destructive fungal grapevine (Vitis vinifera L.) trunk diseases in mature vineyards and are responsible for important crop losses in grapegrowing countries worldwide (Carter 1991; Mugnai et al. 1999; Surico et al. 2006; Úrbez-Torres 2011). Botryosphaeria dieback is commonly associated with over 20 Botryosphaeriaceae species in six different genera (Correia et al. 2013; Linaldeddu et al. 2014; Pitt et al. 2013b; Úrbez-Torres 2011; Úrbez-Torres et al. 2012), which not only include virulent and weak pathogens but also can occur as endophytes (Aroca et al. 2006; Casieri et al. 2009; Giménez-Jaime et al. 2006; González and Tello 2011; Halleen et al. 2005). Diplodia seriata De Not. is the most frequently isolated Botryosphaeriaceae species from diseased grapevines in many countries (Auger et al. 2004; Castillo-Pando et al. 2001; Larignon et al. 2001; Luque et al. 2009; Mohammadi et al. 2013; Phillips 2002; Rovesti and Montermini 1987; Savocchia et al. 2007; Úrbez-Torres et al. 2006, 2008, 2009; van Niekerk et al. 2004; Yan et al. 2013) and it causes different symptoms, including bud mortality, leaf spot and chlorosis, fruit rot, shoot dieback, bud mortality, perennial cankers on grapevines, and vascular necrosis of the wood that appears as wedge-shaped necrosis in cross-sections of the affected plant parts (Úrbez-Torres 2011). Phaeomoniella chlamydospora (W. Gams, Crous, M. J. Wingf. \& Mugnai) Crous \& W. Gams, together with Phaeoacremonium minimum (Tul. \& C. Tul.) D. Gramaje, L. Mostert \& Crous (basionym: P. aleophilum W. Gams, Crous, M. J. Wingf. \& Mugnai), several other Phaeoacremonium spp., and some species of the genus Cadophora Lagerb. \& Melin are considered the primary causal agents of Petri disease in young vineyards. Moreover, these fungi are also involved, together with Fomitiporia mediterranea M. Fisch., in the esca disease of mature vineyards in Mediterranean countries (Bertsch et al. 2013; Fischer 2002; Gramaje et al. 2015; Halleen et al. 2007; Mugnai et al. 1999; Surico et al. 2006). Most recognized foliar symptoms of

Corresponding author: J. Luque; E-mail: jordi.luque@irta.cat

Accepted for publication 7 March 2016.

http://dx.doi.org/10.1094/PDIS-10-15-1186-RE

(C) 2016 The American Phytopathological Society esca are characterized by leaf interveinal discolorations that later result in large necrotic areas (Mugnai et al. 1999; Surico et al. 2006), although these symptoms cannot be associated with the effects of a single pathogen and are likely to occur as a complex interaction of multiple biotic and abiotic factors which are still not fully understood (Bertsch et al. 2013; Surico et al. 2006). In contrast, wood symptoms caused by Phaeomoniella chlamydospora and Phaeoacremonium minimum have been reported as necrotic lesions including a longitudinal brown streaking, appearing as brown spots in cross-sectioned vine parts, longitudinal stripes in cordons and trunks, as well as pink-brown or dark red-brown necrotic areas in the wood (Lecomte et al. 2012; Mugnai et al. 1999). Symptoms caused by F. mediterranea on wood are characterized by a yellowish, spongy decay of the vine woody tissues. It has been shown that severity of wood symptoms could be potentially related to the appearance of foliar symptoms (Maher et al. 2012), although Calzarano and Di Marco (2007) reported that vines with a high level of necrotic lesions did not show foliar symptoms. Therefore, the relationship between the wood deterioration and foliar symptoms is disputed, and other factors might be involved in symptom expression, such as a reduction in xylem flux (Andreini et al. 2009) or the associated actions of fungal mycotoxins (Christen et al. 2007), which still need to be studied in detail. Eutypa dieback is caused by the fungus Eutypa lata (Pers.) Tul. \& C. Tul (Carter 1991). In recent years, an increasing number of Diatrypaceae species have also been isolated from diseased vines and were proven to be pathogenic on grapevine (Díaz et al. 2011; Jordan and Schilder 2007; Luque et al. 2012; Trouillas and Gubler 2010; Trouillas et al. 2010, 2011). However, E. lata is still considered the most important and widespread causal agent of Eutypa dieback worldwide. Foliar symptoms of Eutypa dieback, comprising stunted shoots with short internodes and small, chlorotic, and cupped leaves with marginal necrosis, are thought to be caused by toxic metabolites produced by E. lata; however, the exact role of these metabolites on symptom expression is still unclear (Molyneux et al. 2002; Renaud et al. 1989; Tey-Rulh et al. 1991). Wood symptoms comprise internal necrosis, visualized as a wedge-shaped area of stained tissue if a cross section is made of an infected trunk or cordon, and depressed areas in the cankered wood which develop around the sites of infection (Carter 1991). Botryosphaeria dieback and esca are the most prevalent trunk diseases in Catalonia, Northeast Spain, where the present study was 
carried out. Eutypa dieback is also present in the area but is not as common as the former two diseases (Luque et al. 2009).

It is widely accepted that trunk diseases in mature vineyards are spread by airborne spores of the pathogens which infect pruning wounds while these remain susceptible to infection (Eskalen and Gubler 2001; Larignon and Dubos 2000; Luque et al. 2014; ÚrbezTorres et al. 2010; van Niekerk et al. 2011). The airborne inoculum has been reported to be dispersed in vineyards after periods of rainfall (Eskalen and Gubler 2001; Úrbez-Torres et al. 2010; van Niekerk et al. 2010), overhead sprinkler irrigation (Kuntzmann et al. 2009; Úrbez-Torres et al. 2010), rainwater splash on plant surfaces containing fruiting bodies and spores (Baskarathevan et al. 2013), and in the rainwater runoff (Amponsah et al. 2009). Different studies showed that spore release of Botryosphaeriaceae species and E. lata coincided with the beginning of rain or irrigation events (Carter 1991; Gubler et al. 2005; Michailides and Morgan 1993). However, the end of the spore release may differ among fungi, finishing $2 \mathrm{~h}$ after the end of rainfall or irrigation in case of some Botryosphaeriaceae species, whereas ascospores of $E$. lata were reported to be released up to 36 h later (Carter 1991; Gubler et al. 2005; Paillassa 1992; Pearson 1980; Trouillas and Gubler 2009). Eskalen and Gubler (2001) also showed that spread of airborne inoculum of Phaeomoniella chlamydospora, Phaeoacremonium minimum, and $P$. inflatipes W. Gams, Crous \& M. J. Wingf. is correlated with rainfall events in California. However, Larignon and Dubos (2000) observed that Phaeomoniella chlamydospora conidia were present in the vineyard throughout the whole year in France. The Botryosphaeriaceae species Neofusicoccum parvum (Pennycook \& Samuels) Crous, Slippers \& A. J. L. Phillips and N. luteum (Pennycook \& Samuels) Crous, Slippers \& A. J. L. Phillips were detected in rainwater samples through polymerase chain reaction (PCR)-based methods, thus indicating that conidia of these fungi can be dispersed during a rainfall event (Baskarathevan et al. 2013). In addition, spore-trapping studies in several countries such as the United States (California) (Eskalen and Gubler 2001; Petzoldt et al. 1983; Ramos et al. 1975; ÚrbezTorres et al. 2010), France (Kuntzmann et al. 2009; Larignon and Dubos 2000), New Zealand (Amponsah et al. 2009), and South Africa (van Niekerk et al. 2010) have described the evolution of the airborne inoculum of E. lata, P. chlamydospora, Phaeoacremonium minimum, $P$. inflatipes, Phomopsis spp., and several Botryosphaeriaceae species included in the genera Diplodia Fr., Dothiorella Sacc., and Neofusicoccum Crous, Slippers \& A. J. L. Phillips.

Pruning wounds are often not protected because wound protection treatments are costly; thus, this is only viable in vineyards with a high cash return (Serra et al. 2008; Úrbez-Torres and Gubler 2009). Consequently, when weather conditions during the pruning season are favorable for inoculum release and spread, infections of pruning wounds are most likely to occur (van Niekerk et al. 2011). Susceptibility of pruning wounds to trunk pathogens has been previously studied through artificial inoculations in several grape-growing regions such as California (Eskalen et al. 2007; Gubler et al. 2001; Moller and Kasimatis 1978; Munkvold and Marois 1995; Petzoldt et al. 1981; Úrbez-Torres and Gubler 2011), Michigan (Trese et al. 1980), France (Chapuis et al. 1998; Larignon and Dubos 2000; Lecomte and Bailey 2011), Italy (Serra et al. 2008), and South Africa (van Niekerk et al. 2011). Wound susceptibility has been assessed for D. seriata (Serra et al. 2008), E. lata (Chapuis et al. 1998; Lecomte and Bailey 2011; Munkvold and Marois 1995; Petzoldt et al. 1981; Trese et al. 1980; van Niekerk et al. 2011), Lasiodiplodia theobromae (Pat.) Griffon \& Maubl. (Úrbez-Torres and Gubler 2011), N. australe (Slippers, Crous \& M. J. Wingf.) Crous, Slippers \& A. J. L. Phillips (van Niekerk et al. 2011), N. parvum (ÚrbezTorres and Gubler 2011), P. inflatipes (Gubler et al. 2001), P. minimum (Eskalen et al. 2007; Serra et al. 2008), Phaeomoniella chlamydospora (Eskalen et al. 2007; Gubler et al. 2001; Serra et al. 2008; van Niekerk et al. 2011), and Phomopsis viticola (Sacc.) Sacc. (van Niekerk et al. 2011), usually by inoculating the pathogens at different times after pruning. In general, these studies showed that wound susceptibility decreased as the period between pruning and inoculation of wounds increased. Differences in the susceptibility duration have been found among pathogens, geographic regions, grape variety, age of the vineyard, inoculation time, and pruning seasons and due to the competition in the colonization of pruning wounds with naturally occurring epiphytes (Chapuis et al. 1998; Eskalen et al. 2007; Larignon and Dubos 2000; Lecomte and Bailey 2011; Petzoldt et al. 1981; Serra et al. 2008; Trese et al. 1980; Úrbez-Torres and Gubler 2011; van Niekerk et al. 2011).

In summary, wound susceptibility can be extended up to 4 to 7 weeks for most pathogens under favorable conditions (Chapuis et al. 1998; Munkvold and Marois 1995; Petzoldt et al. 1981) but can be even longer, up to 12 to 16 weeks (Eskalen et al. 2007; Serra et al. 2008; Úrbez-Torres and Gubler 2011). The decrease in wound susceptibility has been associated with the processes related to wound healing, which basically involve the drying of cane tissues below the pruning wound (Bostock and Stermer 1989; Doster and Bostock 1988; Shigo 1984). This results in a dead wood area in the cane called the drying cone (cone de dessèchement) by Lafon (1921) and, later, by Dal et al. (2008) or the dead wood cone (cone de bois mort) by Galet (2000). Dal et al. (2008) stated that wound healing can affect the vascular system below the drying cone by interfering with the sap flow and may even produce an overall weakening of the vine if pruning is not conducted properly, especially in spur-pruned grapevines. However, there is no available information to date about the influence of wound healing on the colonization of canes by pathogenic fungi.

Results obtained in a previous study on the natural infections of pruning wounds in Catalonia showed that higher infection percentages occurred in spring than in winter (Luque et al. 2014), thus suggesting that pruning wounds could be more susceptible to pathogens overall after a late pruning in winter. The current study aimed at continuing this research by determining the effects of the pruning season and wound age on the susceptibility of pruning wounds to D. seriata and Phaeomoniella chlamydospora. In addition, the subsequent colonization process of infected canes was studied for both pathogens by inoculating wounds made on canes with different lengths of pruned internodes.

\section{Materials and Methods}

Plant material. The experiment on the susceptibility of pruning wounds to $D$. seriata and $P$. chlamydospora was conducted in an experimental vineyard located at IRTA facilities in Cabrils, Catalonia, Spain. Seven-year-old potted 'Tempranillo' vines grafted onto Richter 110 rootstock were kept outdoors in 50-liter pots filled with a peat/perlite mixture $(1: 1, \mathrm{vol} / \mathrm{vol})$, and watered adequately to avoid water stress. The experiment on the pathogen colonization of pruned canes was conducted in a commercial 11-year-old 'Chardonnay' vineyard located in El Pla del Penedès, Catalonia. Vines in both vineyards were conducted in bilateral cordons and spur-pruned during the experiments.

Fungal isolates and inoculum preparation. $D$. seriata isolate CBS 121485 and $P$. chlamydospora isolate CBS 121483 were used in the experiments. Both fungi were collected in 2003 from diseased grapevines in Catalonia; $D$. seriata from a cankered cordon of a 'Cabernet Sauvignon' vine and P. chlamydospora from wood necrotic streaking of a 'Carignane' vine showing esca symptoms. Fungi were maintained at $4^{\circ} \mathrm{C}$ as mycelial plugs contained in tubes filled with sterile distilled water. Inoculations were performed with conidial suspensions of each pathogen obtained as follows. A mycelial plug of D. seriata previously grown on Difco potato dextrose agar (PDA; Becton, Dickinson and Co., Sparks, MD) for 7 days at $25^{\circ} \mathrm{C}$ was put on a center of a water agar plate (Bacto Agar; Becton, Dickinson and Co.). Several sterile fragments (approximately $n=20$ ) of stone pine (Pinus pinea L.) needles ( $1 \mathrm{~cm}$ long) were put on the media surface at about $1.5 \mathrm{~cm}$ surrounding the mycelial plug. Plates were incubated for 4 weeks at $25^{\circ} \mathrm{C}$ under combined near-UV and white fluorescent light (Philips TL-D 18W BLB and Sylvania Standard F18W/33-640-TS cool white, respectively) at a photoperiod of 12 and $12 \mathrm{~h}$, until pycnidia formation. One day before inoculation, pine needles (approximately $n=40$ ) with $D$. seriata pycnidia were placed in a beaker containing $30 \mathrm{ml}$ of sterile distilled water. The 
solution was kept overnight (approximately $16 \mathrm{~h}$ ) at $4{ }^{\circ} \mathrm{C}$ to prevent conidia germination, and in constant agitation with the help of a magnetic stirrer to induce conidia release from the pycnidia. On the next day, the suspension was vacuum-filtered through a $60-\mu \mathrm{m}$ Steriflip filter (Millipore Corporation, Billerica, MA) to get a cleaner suspension. The conidial suspension was adjusted to $2 \times 10^{4}$ conidia $/ \mathrm{ml}$ using a hemocytometer. Phaeomoniella chlamydospora was grown on PDA plates for 3 weeks at $25^{\circ} \mathrm{C}$. On the same day of inoculations, $10 \mathrm{ml}$ of sterile distilled water was added to the $P$. chlamydospora culture, which was gently scraped with a sterile cotton stick to release conidia. The conidial suspension was collected and adjusted to $4 \times$ $10^{4}$ conidia/ml using a hemocytometer. Spore suspensions were stored at $4^{\circ} \mathrm{C}$ until inoculation to avoid early conidia germination.

Inoculation procedures and experimental design. The experiment on wound susceptibility consisted of two independent trials, one for each pathogen, and with two different corresponding pruning dates: first pruning in mid-November (early pruning) and second pruning in mid-February (late pruning). On both pruning dates, a sufficient number of canes was long pruned by leaving four to five buds per cane and $5 \mathrm{~cm}$ between the pruning wound and the top node. All wounds from this experiment were covered with a nylon 5- $\mu \mathrm{m}$ mesh (NITEX; SEFAR, Heiden, Switzerland) to prevent posterior natural infections (especially by $D$. seriata), which were reported to be very high in this wine region (Luque et al. 2014) and, thus, could interfere with the results of the present study. On subsequent inoculation rounds, pruned canes were temporarily uncovered for inoculations and covered again with the NITEX mesh, as described below. Pruning wounds were separately inoculated with either pathogen using a micropipette to place a drop of $50 \mu \mathrm{l}$ of the conidial suspension on each wound, resulting in $10^{3}$ conidia of $D$. seriata and $2 \times 10^{3}$ conidia of $P$. chlamydospora per wound, amounts determined in previous research (Elena et al. 2015) as appropriate to get 50 to $70 \%$ successful infections. Canes were inoculated 1 day and 1, 2, 4, 8, and 12 weeks after pruning. Control pruned canes were treated similarly with $50 \mu \mathrm{l}$ of sterile distilled water instead of the pathogen inoculum and were also covered with the NITEX mesh. Inoculum drops placed on wounds were left to air dry (for several minutes to $1 \mathrm{~h}$ ) before being covered again with the NITEX mesh. Twenty canes per treatment were used as replicates in each combination of pruning date, pathogen, and inoculation date. The experiment was set up in a full randomized design, with three canes in the same cordon of a vine treated with the two pathogens plus the control. The experiment was repeated in two consecutive seasons (2012-13 and 2013-14), with the following pruning dates: first repetition on 13 November 2012 and 8 February 2013, and second repetition on 13 November 2013 and 5 February 2014.

In the pathogen colonization experiment, canes were pruned in midwinter (January). Two different lengths $(2$ and $5 \mathrm{~cm}$ ) between the uppermost node and the pruning wound were left after pruning, for a total of 40 canes per pathogen and internode length. Pruning wounds were separately inoculated with the pathogens, as explained above. All pruning wounds were covered with NITEX after the inoculations. A control treatment consisting of 40 canes was also included and treated with sterile distilled water instead of pathogens. The experiment was set up in a complete randomized design, with three treated canes in the same cordon of a vine. The experiment was repeated in two consecutive years (2013 and 2014), with the following pruning dates: first repetition on 10 January 2013 and second repetition on 15 January 2014.

Isolation procedures. In the experiment on wound susceptibility, fungal recovery was done to assess fungal infection 4 months after each inoculation date. Canes were cut about $20 \mathrm{~cm}$ below the pruning wounds and stored at $4{ }^{\circ} \mathrm{C}$ until further use. All canes were processed for fungal reisolations within a 48-h period after their collection. In the laboratory, bark of canes was removed with a sterile scalpel from the top 5-cm internode, including the pruning wound. The top $2 \mathrm{~mm}$ of the cane, including the pruning wound area, was removed with sterile pruning shears and two fragments of approximately $5 \mathrm{~mm}$ each were cut immediately below. Fragments were surface sterilized by soaking in $70 \%$ ethanol for $4 \mathrm{~min}$. After air drying on sterile filter paper to remove excess ethanol, fragments were plated on petri dishes containing PDA amended with streptomycin sulfate at $50 \mathrm{mg} \cdot \mathrm{liter}^{-1}$. Plates were incubated at $25^{\circ} \mathrm{C}$ until fungal colony growth allowed for pathogen reisolation and subsequent identification based on previously described morphological features (D. seriata, Phillips et al. 2007; P. chlamydospora, Crous and Gams 2000). Recovery percentages for each pruning date, pathogen, and inoculation date were calculated from the pathogen reisolation frequencies.

Regarding the experiment on cane colonization, pathogen recovery was carried out at 5 and 9 months after inoculations (June and October, respectively) in half of the total inoculated canes in each recovery date. The procedures for bark removal, wood chip cuttings, wood surface sterilization, and plating were done as previously described. However, in order to estimate cane colonization for each pathogen, reisolations were attempted from cane sections taken at different distances from the pruning wound (Fig. 1). In the case of the $2-\mathrm{cm}$ pruned internode, reisolations were attempted at $0.5,1.5$, and $4.5 \mathrm{~cm}$ below the pruning wound. The latter point was located about $0.5 \mathrm{~cm}$ below the uppermost node. In the case of the $5-\mathrm{cm}$ pruned internode, reisolations were attempted at the same sites as above (all of them over the uppermost node) and from a fourth site, $0.5 \mathrm{~cm}$ below the node and approximately $7.5 \mathrm{~cm}$ below the pruning wound. Recovery percentages for each combination of pathogen, recovery date, and recovery site were calculated from the reisolation frequencies.

Weather data. In the experiment on wound susceptibility, daily average values of temperature and relative humidity as well as accumulated rainfall were collected from an automatic weather station owned by the Weather Service of the Catalan Regional Government, located about $100 \mathrm{~m}$ from the vineyard. Weather records for the whole experimental period were obtained through the Weather Service and summarized weekly before analyses.

Statistical analyses. Data recorded from the control groups in both experiments were used only to estimate the ratios of natural infections of pruning wounds caused by airborne inoculum of $D$. seriata and $P$. chlamydospora; therefore, they were not included in the statistical analyses. Recovery data of both pathogens obtained in each experiment were analyzed using SAS Enterprise Guide (v4.2) running on SAS statistical software (v9.2; SAS Institute Inc., Cary, NC). Data of percent recoveries were transformed using the arcsine of the square root of the proportion prior the analyses. Analyses of variance (ANOVA) for the main factors and their two-way interaction effects on the dependent variables were performed using the mixed-models option, where repetition of experiments was considered as a random factor and the remaining independent variables as fixed. The residual maximum-likelihood method was used to estimate

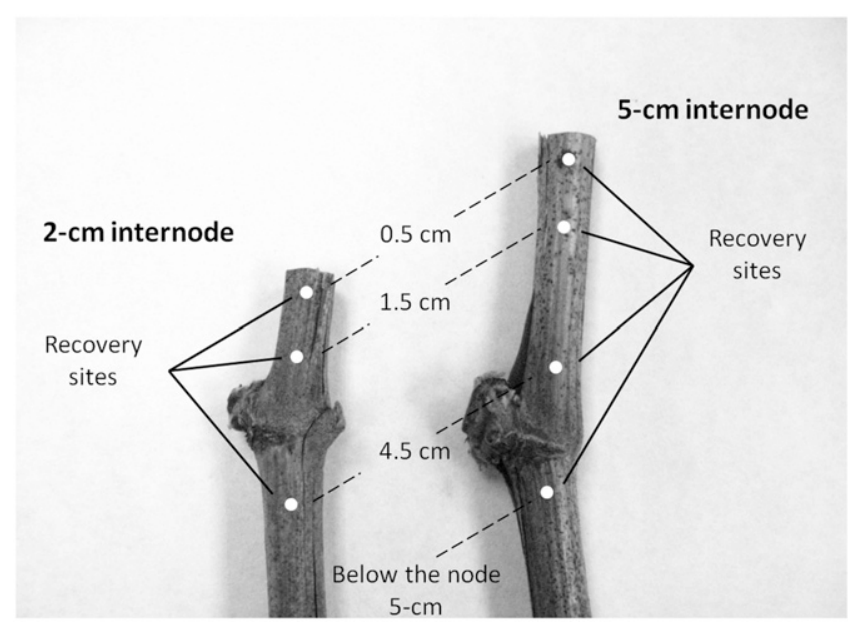

Fig. 1. Short $(2 \mathrm{~cm}$, left) and long $(5 \mathrm{~cm}$, right) internodes showing the approximate sites of mycelium recovery for Diplodia seriata and Phaeomoniella chlamydospora in the grapevine cane colonization experiment. 
the variance components. Separate analyses were done for each pathogen and experiment type. Means were separated using Fisher's least significant difference test at the 5\% significance level after ANOVA. Additional independent mean comparisons were performed through Student's $t$ test, when appropriate. In the experiment on wound susceptibility, Pearson correlation coefficients were calculated between mycelium recovery and weather data.

\section{Results}

In both experiments, $D$. seriata and $P$. chlamydospora were recovered at variable rates from artificially inoculated pruning wounds (Figs. 2, 3, 4, and 5). Natural infections by D. seriata in the control of the wound susceptibility experiment ranged between 0 and $5 \%$ in all repetitions. In the cane colonization experiment, natural infections by $D$. seriata ranged between 0 and $10 \% 5$ months after inoculation and between 55 and $70 \% 9$ months after inoculation. No natural infection of $P$. chlamydospora was detected in any experiment.

Wound susceptibility. Pruning date had no significant effects on the mycelium recovery of $D$. seriata $(F=2.35, P=0.3677)$. However, the effects of the inoculation date after pruning $(F=36.53$, $P=0.0006)$ and its interaction with the pruning date $(F=3.38$, $P=0.0052$ ) proved to be highly significant on the mycelium recovery of $D$. seriata; therefore, the whole dataset was split into two subsets according to the pruning dates and data were reanalyzed. Mycelium recovery of $D$. seriata was $97.5 \%$ when inoculated 1 day after pruning, regardless of the pruning date (Fig. 2). When the pathogen was inoculated 1 week after pruning, recovery percentages were around $70 \%$ regardless of pruning date but, thereafter, the patterns of decrease in mycelium recovery were different between pruning dates (Fig. 2). Whereas inoculation 2 weeks after pruning resulted in $65 \%$ mycelium recovery in the case of a late pruning, the same value for an inoculation after an early pruning was reduced to $35 \%$. The mycelium recovery progressively decreased as the time between pruning and inoculations increased, and resulted in mean values around $10 \%$ for both pruning dates at the end of the experimental period (Fig. 2). Mycelium recovery of $P$. chlamydospora showed a significant decrease $(F=9.00, P=0.0154)$ dependent on the time of inoculation, whereas no statistical significances were detected for the effects of the pruning date $(F=0.10, P=0.8072)$ and the

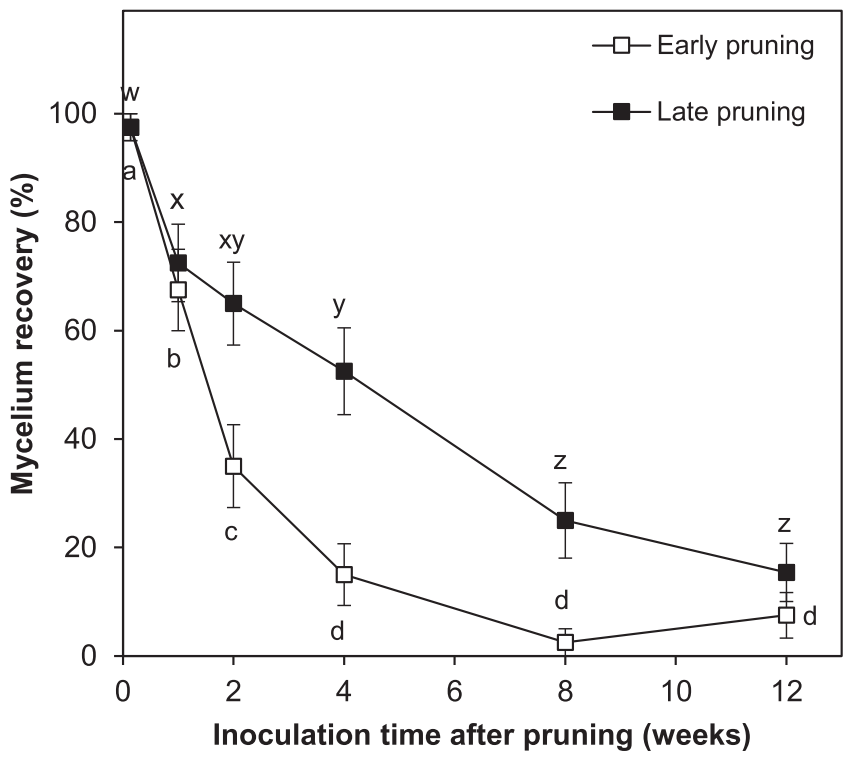

Fig. 2. Mean percentages of mycelium recovery of Diplodia seriata inoculated on 'Tempranillo' canes pruned at different dates; an early pruning in November (white squares) and a late pruning in February (black squares). Forty replications in two independent experiments were used in each combination of pruning and inoculation date. Significant differences among means $(P<0.05)$ are indicated by different letters (a to $d$ for the early pruning, and $w$ to $z$ for the late pruning). Bar errors correspond to the standard error of the mean. two-way interaction of the main factors $(F=1.22, P=0.2977)$. For both pruning dates, mycelium recovery of $P$. chlamydospora was $75 \%$ when wounds were inoculated 1 day after pruning. Percentages of mycelium recovery decreased with inoculation dates in a similar way, regardless of pruning date (Fig. 3). Values corresponding to inoculations done 2 weeks after pruning were around $50 \%$, compared with about $25 \%$ when canes were inoculated 8 weeks after pruning (Fig. 3). Values corresponding to inoculations done 4 weeks after pruning were dissimilar between pruning dates but coincided thereafter. Recovery percentages were around $10 \%$ when inoculations were done 12 weeks after pruning, regardless of pruning date.

Weather data for both experiment repetitions and pruning dates are shown in Table 1. In the first repetition (2012-13), mean temperature and relative humidity decreased over the inoculation dates after early pruning (from 15.1 to $8.2^{\circ} \mathrm{C}$ and from 71.7 to $54.6 \%$, respectively), whereas they increased over inoculation dates after late pruning (from 8.2 to $14.8^{\circ} \mathrm{C}$ and from 54.6 to $70.3 \%$, respectively). Accumulated rainfall ranged from 1.2 to $7.0 \mathrm{~mm}$ after the early pruning and from 1.2 to $18.3 \mathrm{~mm}$ after the late pruning. However, evolution patterns in these variables were irregular and showed partial low and high values within the experimental period (Table 1). In the second repetition (2013-14), evolution patterns of mean temperature and relative humidity were similar to those of the previous season, although an increase in mean temperature was noticed in the last three inoculation periods during early pruning (Table 1 ). Mean values of temperature ranged from 8.6 to $13.5^{\circ} \mathrm{C}$ during the early pruning period and from 11.4 to $15.8^{\circ} \mathrm{C}$ during late pruning. Mean relative humidity records ranged from 50.4 to 79.0 and 56.7 to $71.9 \%$ for the early and late pruning periods, respectively. Whereas accumulated rainfall after late pruning in both experimental repetitions was comparable (43 and $42 \mathrm{~mm}$, respectively), an unusual rainy period (over $130 \mathrm{~mm}$ ) was recorded for the week following the inoculations 1 day after pruning in the early pruning of 2013-14 (Table 1).

Significant positive correlations were found between recovery percentages of $D$. seriata and temperature after the early pruning carried out in 2012-13 $\left(r^{2}=0.89, P=0.0181\right)$. However, significant negative correlations were found between recovery percentages of $D$. seriata and temperature and between recovery percentages of $P$. chlamydospora

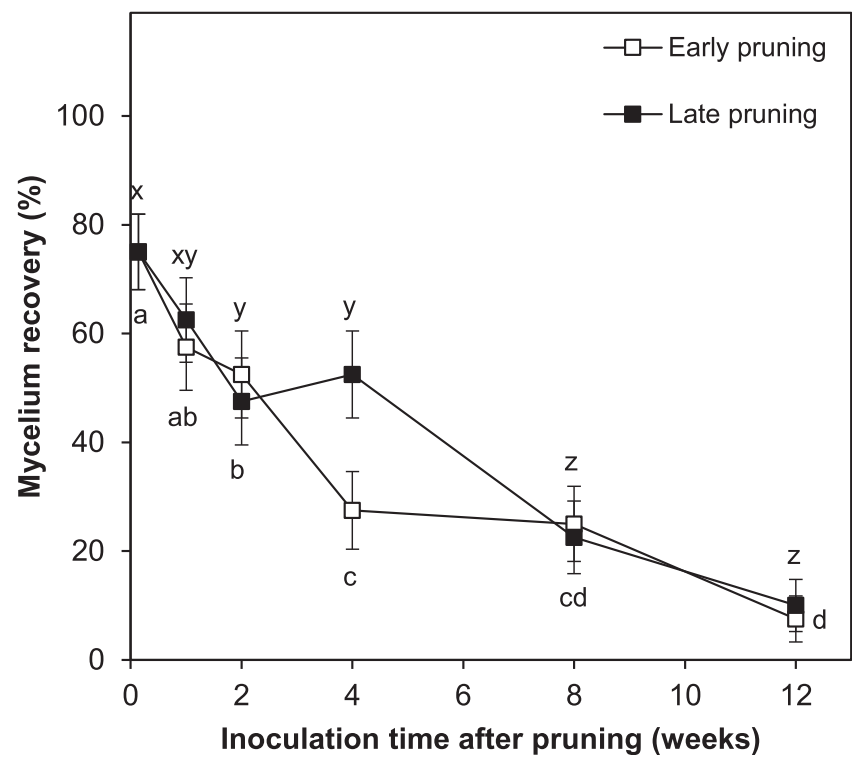

Fig. 3. Mean percentages of mycelium recovery of Phaeomoniella chlamydospora inoculated on 'Tempranillo' canes pruned at different dates; an early pruning in November (white squares) and a late pruning in February (black squares). Forty replications in two independent experiments were used in each combination of pruning and inoculation date. Significant differences among means $(P<0.05)$ are indicated by different letters ( $a$ to $d$ for the early pruning and $x$ to $z$ for the late pruning). Bar errors correspond to the standard error of the mean. 
and temperature after the late pruning carried out in 2012-13 $\left(r^{2}=\right.$ $-0.89, P=0.0167$ and $r^{2}=-0.81, P=0.0497$, respectively). No other significant correlations were found between recovery percentages of pathogens and the meteorological data (Table 2). Additional correlations were calculated for the recovery percentages and weather data for extended periods after inoculations ( 2 and 3 weeks) but no significant results were obtained and, thus, they are not shown here.

Cane colonization. Recovery date had no significant effect on the overall mycelium recovery of $D$. seriata and $P$. chlamydospora from inoculated canes (Table 3). However, significant differences in the mycelium recovery at the different recovery sites were detected for both pathogens (Table 3; Figs. 4 and 5). Moreover, a significant interaction between the recovery date and the recovery site was detected for $D$. seriata at any length of the pruned internode, whereas no interaction between the same factors was observed for P. chlamydospora (Table 3). Mycelium recovery percentages for both pathogens significantly decreased as the length between the pruning wound and the recovery site increased (Figs. 4 and 5). A visual inspection of the pruned internodes made during the reisolations showed that $25 \%$ of the $2-\mathrm{cm}$ pruned internodes and $5 \%$ of the $5-\mathrm{cm}$ pruned internodes appeared to be completely or partially dried 5 months after inoculation. However, the same figures in reisolations at the end of the experimental period (9 months) were 100 and $95 \%$, respectively, thus indicating that effective internode drying occurred between and coinciding with the summer season. No substantial differences were observed between the repetitions of the experiment.

At 5 months after inoculation, mycelium recovery of $D$. seriata from the two uppermost recovery sites $(0.5$ and $1.5 \mathrm{~cm})$ ranged between 67.5 and $90.0 \%$ regardless of the pruned internode length; however, significant differences were detected between both recovery sites for each internode length (Fig. 4). Mycelium recovery of D. seriata at $4.5 \mathrm{~cm}$ below the pruning wound was $5 \%$ in canes with 2 -cm pruned internodes and $40 \%$ in canes with 5 -cm pruned internodes, whereas no reisolation was obtained below the top node in 5-cm pruned internodes (Fig. 4). At 9 months after inoculation, no differences in mycelium recovery of $D$. seriata were found within the two and three uppermost recovery sites in canes with 2- and 5 -cm pruned internodes, respectively, with mean values ranging from 90.0 to $97.5 \%$ (Fig. 4). However, recovery below the node remained significantly lower than from upper sites, even though percentages had increased to $32.5 \%$ (2-cm internode length) and $40.0 \%$ (5-cm internode length) from the previous recovery date. Significant differences in recoveries at $4.5 \mathrm{~cm}$ below the pruning wound were found between the 2 - and 5 -cm pruned internodes 5 and 9 months after inoculation $(t=4.33, P<0.0001$ and $t=7.56, P<0.0001$, respectively).

Mycelium recovery of $P$. chlamydospora in the two uppermost reisolation sites ranged between 60 and $85 \%$ regardless of the internode length and recovery date, and significant differences between both recovery sites were found only in 5-cm internodes and 5 months after inoculation (Fig. 5). Mycelium recovery percentages from the $4.5-\mathrm{cm}$ recovery site were always significantly lower than values from the uppermost sites, regardless of the pruned internode length and the recovery date. However, no significant differences in mycelium recovery at the $4.5-\mathrm{cm}$ site between the 2 - and $5-\mathrm{cm}$ pruned internodes were detected at either recovery date $(t=1.79, P=0.0770$ and $t=$ $1.50, P=0.1364$, respectively). Recovery percentages below the node were equal to or lower than $20 \%$ regardless of the internode length and recovery date (Fig. 5).

The overall mean of $D$. seriata recovery 5 months after inoculations was $54.2 \%$ for the $2-\mathrm{cm}$ pruned internodes and $48.8 \%$ for the 5 -cm pruned internodes, which includes the reisolations attempted on all processed wood chips regardless of the reisolation site. At the end of the experimental period, the equivalent values were 70.8 and $80.5 \%$, respectively. The overall mean of $P$. chlamydospora recovery 5 months after inoculation was $59.8 \%$ for the $2-\mathrm{cm}$ pruned internodes and $46.9 \%$ for the $5-\mathrm{cm}$ pruned internodes. At the end of the experimental period, the equivalent values were 50.0 and $43.1 \%$, respectively.

\section{Discussion}

Susceptibility of grapevine pruning wounds to the fungal pathogens $D$. seriata and $P$. chlamydospora, as well as the colonization of either short $(2 \mathrm{~cm})$ or long $(5 \mathrm{~cm})$ pruned canes, were evaluated after artificial inoculations with each pathogen. Wound susceptibility decreased as the time between pruning and inoculations increased for both pathogens. Inoculations made 12 weeks after pruning were still susceptible and yielded recovery percentages of $D$. seriata and $P$. chlamydospora around $10 \%$. Although pruning wounds were covered with a NITEX mesh to protect them from high rates of natural infections observed in this wine region (Luque et al. 2014), results of the present study were in accordance with findings of previous research in different countries and under different climate conditions, which confirmed that pruning wounds remained susceptible to these two fungi up to 4 months after pruning (Eskalen et al. 2007; Gubler et al. 2001; Serra et al. 2008).

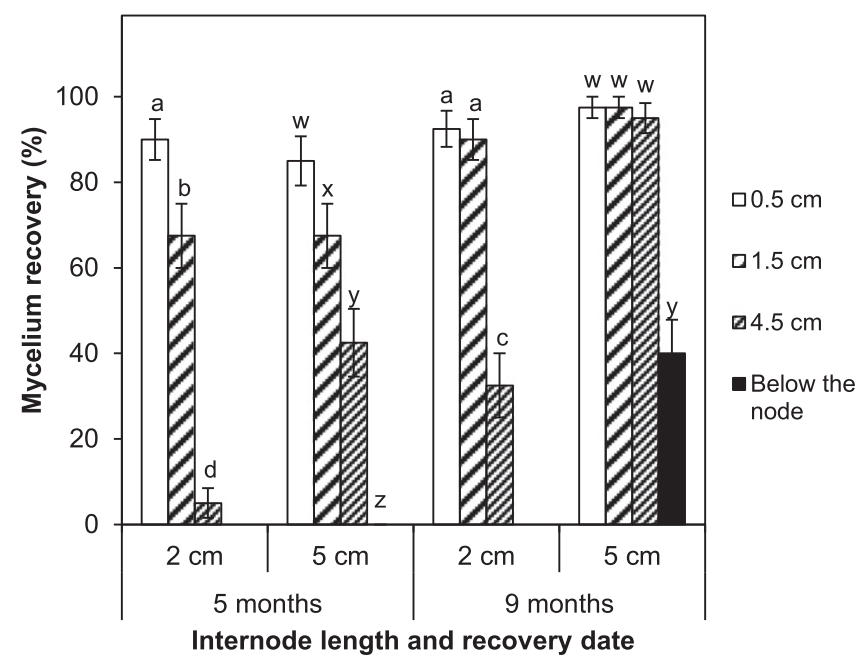

Fig. 4. Mean percentages of mycelium recovery of Diplodia seriata inoculated on 'Chardonnay' pruned canes and reisolated from different recovery sites in canes of 2- and 5-cm internode length, corresponding to two different incubation periods (5 and 9 months) after pruning. Forty replications in two independent experiments were used in each combination of recovery site, internode length, and recovery date. Significant differences $(P<0.05)$ among means for each recovery site are indicated separately by different letters ( $a$ to $c$ for the $2-\mathrm{cm}$ internodes and $\mathrm{w}$ to $\mathrm{z}$ for the $5-\mathrm{cm}$ internodes). Bar errors correspond to the standard error of the mean.

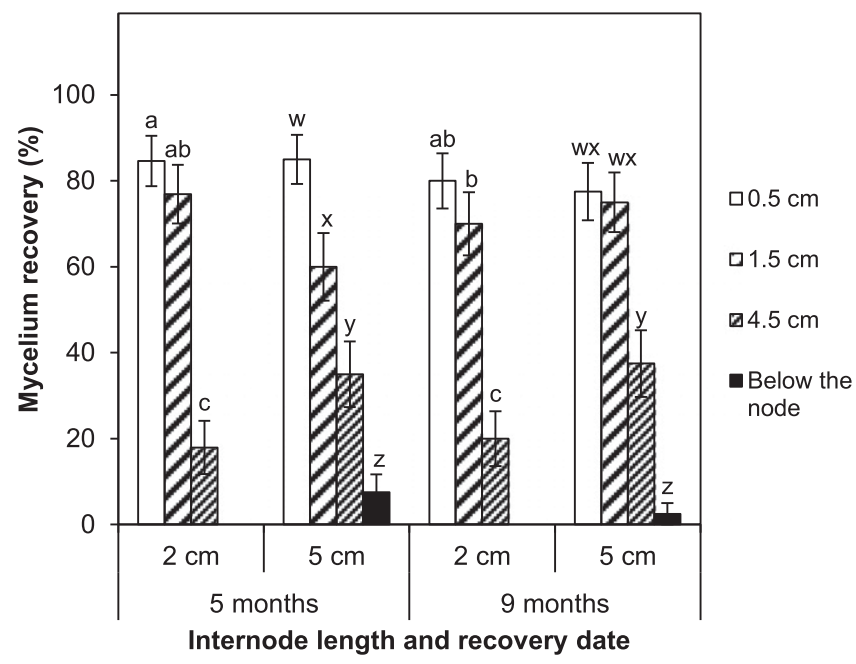

Fig. 5. Mean percentages of mycelium recovery of Phaeomoniella chlamydospora inoculated on 'Chardonnay' pruned canes and reisolated from different recovery sites in canes of 2- and 5-cm internode length corresponding to two different incubation periods ( 5 and 9 months) after pruning. Forty replications in two independent experiments were used in each combination of recovery site, internode length, and recovery date. Significant differences $(P<0.05)$ among means for each recovery site are indicated separately by different letters (a to $c$ for the 2-cm internodes and $\mathrm{w}$ to $\mathrm{z}$ for the 5-cm internodes). Bar errors correspond to the standard error of the mean. 
Moreover, these results also would suggest that NITEX mesh would not have a substantial influence on the susceptibility of pruning wounds. However, this study and those previously cited based their conclusions on artificial inoculations of canes, in which inoculum potentials of pathogens are usually overrated compared with the natural occurring inoculum pressure; and, thus, the wound susceptibility period could be overestimated. To date, no data are available on the susceptibility of wounds naturally infected and this remains to be further studied.

Seasonal differences in wound susceptibility to $D$. seriata were found to depend on the pruning season. A rapid decrease down to $35 \%$ infected canes was observed 2 weeks after an early pruning whereas a comparable decrease was not found until 8 weeks after a late pruning. These latter results were consistent with those reported by Serra et al. (2008), who found that, in Italy, pruned canes of 'Sauvignon Blanc' remained susceptible to $D$. seriata up to 8 weeks after a pruning done in March. Moreover in South Africa, pruning wounds of 'Chenin Blanc' grapevines remained susceptible longer to the Botryosphaeriaceae species $N$. australe (Slippers, Crous \& M. J. Wingf.) Crous, Slippers \& A. J. L. Phillips when wounds were made and inoculated in late winter versus in midwinter (van Niekerk et al. 2011). However, in a study carried out in California by ÚrbezTorres and Gubler (2011) with two other Botryosphaeriaceae fungi (namely, L. theobromae and N. parvum), wound susceptibility to pathogens was significantly higher in early winter (December to January) than in late winter (February to March). Moreover, ÚrbezTorres and Gubler (2011) observed a high rate of infection after an earlier pruning done in November. Luque et al. (2014) detected a higher percentage of natural infections of $D$. seriata in Catalonia, Northeast Spain after a late pruning done in February. These results are in accordance with those obtained here, because an overall increased period of wound susceptibility in spring would support a higher incidence of natural infections caused by $D$. seriata on grapevines in this wine region.

No seasonal differences were found in wound susceptibility in the case of $P$. chlamydospora, because the pattern of decrease in wound

Table 1. Mean temperature, mean relative humidity, and accumulated rainfall during the 1-week period after each inoculation date in the wound susceptibility experiment ${ }^{\mathrm{a}}$

\begin{tabular}{|c|c|c|c|c|}
\hline $\begin{array}{l}\text { Year, pruning } \\
\text { season }\end{array}$ & $\begin{array}{c}\text { Inoculation } \\
\text { date }\end{array}$ & $\begin{array}{c}\text { Temperature } \\
\left({ }^{\circ} \mathrm{C}\right)\end{array}$ & $\begin{array}{c}\text { Relative } \\
\text { humidity } \\
(\%)\end{array}$ & $\begin{array}{l}\text { Accumulated } \\
\text { rainfall }(\mathbf{m m})\end{array}$ \\
\hline \multicolumn{5}{|l|}{$2012-13$} \\
\hline \multirow[t]{6}{*}{ Early pruning } & 1 day & $15.13 \pm 0.36$ & $71.7 \pm 4.9$ & 7.0 \\
\hline & 1 week & $13.40 \pm 0.37$ & $78.1 \pm 1.1$ & 1.2 \\
\hline & 2 weeks & $8.46 \pm 0.64$ & $54.7 \pm 2.6$ & 0.0 \\
\hline & 4 weeks & $12.11 \pm 1.13$ & $65.7 \pm 4.0$ & 2.1 \\
\hline & 8 weeks & $8.24 \pm 0.28$ & $67.0 \pm 3.0$ & 2.5 \\
\hline & 12 weeks & $8.21 \pm 0.64$ & $54.6 \pm 3.3$ & 0.0 \\
\hline \multirow[t]{6}{*}{ Late pruning } & 1 day & $8.21 \pm 0.64$ & $54.6 \pm 3.3$ & 0.0 \\
\hline & 1 week & $10.11 \pm 0.31$ & $69.0 \pm 4.8$ & 1.2 \\
\hline & 2 weeks & $6.94 \pm 1.07$ & $68.7 \pm 4.3$ & 11.1 \\
\hline & 4 weeks & $10.6 \pm 0.74$ & $65.9 \pm 4.0$ & 5.7 \\
\hline & 8 weeks & $11.05 \pm 0.81$ & $68.7 \pm 4.6$ & 18.3 \\
\hline & 12 weeks & $14.81 \pm 0.38$ & $70.3 \pm 1.4$ & 6.8 \\
\hline \multicolumn{5}{|l|}{ 2013-14 } \\
\hline \multirow[t]{6}{*}{ Early pruning } & 1 day & $13.5 \pm 0.6$ & $66.7 \pm 6.5$ & 130.6 \\
\hline & 1 week & $8.8 \pm 0.2$ & $50.4 \pm 2.9$ & 0.0 \\
\hline & 2 weeks & $8.6 \pm 0.9$ & $51.3 \pm 2.3$ & 0.7 \\
\hline & 4 weeks & $9.9 \pm 0.4$ & $73.6 \pm 2.6$ & 0.0 \\
\hline & 8 weeks & $10.3 \pm 0.5$ & $79.0 \pm 2.3$ & 4.9 \\
\hline & 12 weeks & $11.4 \pm 0.7$ & $59.6 \pm 3.2$ & 15.5 \\
\hline \multirow{6}{*}{ Late pruning } & 1 day & $11.4 \pm 0.7$ & $59.6 \pm 3.2$ & 15.5 \\
\hline & 1 week & $12.3 \pm 0.8$ & $66.0 \pm 3.5$ & 8.2 \\
\hline & 2 weeks & $10.4 \pm 0.3$ & $70.4 \pm 3.2$ & 4.2 \\
\hline & 4 weeks & $12.2 \pm 0.3$ & $56.7 \pm 3.2$ & 0.0 \\
\hline & 8 weeks & $14.9 \pm 0.3$ & $71.9 \pm 3.7$ & 14.0 \\
\hline & 12 weeks & $15.8 \pm 0.2$ & $70.4 \pm 1.8$ & 0.2 \\
\hline
\end{tabular}

${ }^{a}$ Mean values are followed by \pm standard error when appropriate. susceptibility was similar regardless of the pruning date. Serra et al. (2008) also reported a decrease of susceptibility to $P$. chlamydospora during the growing season without clear differences in susceptibility between pruning dates. Larignon and Dubos (2000) showed that wound susceptibility to $P$. chlamydospora occurred about 7 to 9 weeks after a midwinter pruning (January) but only 1 to 2 weeks after a latewinter pruning (March) in France. However, results of susceptibility duration obtained by Larignon and Dubos (2000) were highly variable among the different experimental repetitions, suggesting that factors other than the host and the pathogen could be involved in the wound susceptibility duration. Gubler et al. (2001) observed vascular streaking in pruning wounds inoculated with $P$. chlamydospora from February to June, indicating that grapevine tissue was susceptible to the infection from dormancy to green, actively growing tissue. Luque et al. (2014) reported a strong seasonal effect in the natural infections of pruned canes by $P$. chlamydospora in Catalonia, where infections after a late winter pruning were more frequent than those observed after an early pruning in fall. Results included in this study would indicate that wound susceptibility is similar in both pruning seasons; therefore, the seasonal differences in natural infections recorded by Luque et al. (2014) could be related to the availability of the infective inoculum of $P$. chlamydospora in each pruning season.

Significant correlations between weather data and recovery percentages were rarely observed in this study and they were only found between temperature and pathogen recovery in the first repetition carried out in 2012-13, whereas no significant correlations were found in 2013-14. Correlation coefficients between temperature and recovery percentages for $D$. seriata and $P$. chlamydospora were positive after an early pruning and negative after a late pruning, because the decrease in wound susceptibility after the early pruning coincided with a decrease in recorded temperatures and the decrease in spring was coincident with increasing temperatures. Serra et al. (2008) observed high infection rates of pruning wounds by $D$. seriata during episodes of high temperatures and also regularly distributed rainfall in Italy, which is similar to that observed in this study. However, in California, susceptibility of pruning wounds to infection by $L$. theobromae and $N$. parvum decreased as the temperature in spring increased (Úrbez-Torres and Gubler 2011). Other studies carried out with E. lata in California (Munkvold and Marois 1995; Trese et al. 1980) and France (Chapuis et al. 1998) reported that pruning wounds were less susceptible under increasing temperature conditions. Chapuis et al. (1998) also suggested that other microorganisms found in the wound might interfere with the colonization of the pathogen. These results show that susceptibility of grapevine pruning wounds may be affected by different abiotic and biotic conditions and might vary among geographic regions and pathogenic fungi. Therefore, it is suggested that pruning wound susceptibility should be studied on a local or regional basis to better understand this host-pathogen interaction within the infection process.

In the cane colonization experiment, natural infections by $D$. seriata at the last assessment ranged between 55 and $70 \%$, thus indicating that the NITEX mesh used to protect pruning wounds did not prevent natural airborne infections caused by this pathogen. It is also suggested that inoculum already present on the bark close to the wound or as latent infections in the bark may have contributed to the high natural infection rates of this pathogen. In fact, Billones-Baaijens et al. (2015) reported that grapevine wood infection by the Botryosphaeriaceae species $N$. luteum and $N$. parvum may have originated from bark latent infections. This should be studied for the specific case of D. seriata. In addition, it has been reported that pruning shears could act as vectors in pathogen dissemination (Agustí-Brisach et al. 2015), thus making wound protection with NITEX mesh useless if mechanical transmission of $D$. seriata occurred during pruning. However, regardless of the high percentages of natural infections by $D$. seriata in our experiment, recovery of $P$. chlamydospora could be assessed properly. D. seriata showed an overall higher potential for cane colonization than $P$. chlamydospora, as concluded from the recovery percentages of the pathogens based on infected canes and recovery dates. The higher recovery percentages of $D$. seriata 
at the end of the experiment (9 months) in all assessed recovery sites would support an easier recovery of this fungus compared with $P$. chlamydospora. These results are in accordance with growth data of these pathogens observed in vitro, because it is expected that a higher in vitro growth rate would allow quantitatively rapid cane colonization for the fungus. Úrbez-Torres et al. (2006) reported an in vitro growth rate of $D$. seriata of approximately $25 \mathrm{~mm}$ per $48 \mathrm{~h}$, whereas Pitt et al. (2013a) estimated a rate about 15 to $20 \mathrm{~mm} /$ day at 25 to $27^{\circ} \mathrm{C}$ for the same species. Tello et al. (2010) estimated a growth rate for $P$. chlamydospora in the range 0.7 to $1.4 \mathrm{~mm} /$ day, whereas Whiting et al. (2001) reported a maximum rate of growth $<2 \mathrm{~mm} /$ day at $25^{\circ} \mathrm{C}$. However, Troccoli et al. (2001) reported that $P$. chlamydospora required 9 months to colonize the first 20 to $25 \mathrm{~cm}$ of grapevine stems in 1-year-old potted micropropagated vines (1103 Paulsen rootstock). This contradicts our results but great differences in the experimental conditions of these two studies (e.g., plant age and variety, inoculation and recovery methods, and virulence of strains) could explain those differences. In a previous pathogenicity test with the same strains used here (formerly named $D$. seriata strain 398 and $P$. chlamydospora strain 454), both pathogens showed vascular necrosis of similar size $(2.4$ to $4.5 \mathrm{~cm})$ on 'Macabeo' and 'Tempranillo' grapevines (Luque et al. 2009); however, recovery at different distances from the site of inoculation was not performed and cane colonization rates for both pathogens were not estimated.

The healing of pruning wounds, as characterized by the drying of the pruned internode tissues, would not have limited the cane colonization by $D$. seriata, because recovery percentages were higher at the end of the experimental period than in the first assessment. Moreover, recovery percentages were greater in lower recovery sites, especially at recovery sites 1.5 and $4.5 \mathrm{~cm}$ below the wound, thus confirming the progression of the pathogen downward the cane. In contrast, overall recovery percentages of $P$. chlamydospora were only slightly reduced at the end of the experimental period, which suggests that cane colonization and fungal survival could be limited by cane drying. However, this hypothesis would need further research to be confirmed. Regarding the potential effect of the internode length on the cane colonization by pathogens, results showed that the mycelium recovery of D. seriata was over $90 \%$ in the three uppermost sites of the 5 -cm internodes after 9 months of incubation. However, recovery percentage below the node in $2-\mathrm{cm}$ internodes (i.e., $4.5 \mathrm{~cm}$ below the pruning wound) was significantly reduced compared with the equivalent site in 5 -cm internodes. This would suggest that the node may limit the rate of cane colonization by this pathogen; however, $D$. seriata reached the living tissues below the top node in similar percentages regardless of the pruned internode length at the end of the experiment. Data on cane colonization by $P$. chlamydospora showed that pathogen recovery at $4.5 \mathrm{~cm}$ below the pruning wound was similar in 2- and 5-cm internodes at the end of the experiment. This would reject the hypothesis that the node may make cane colonization by $P$. chlamydospora difficult. This fungus is able to move actively in vessels and in the pith (Pascoe and Cottral 2000; Troccoli et al. 2001), and it is suspected that the fungus may spread into canes by movement of spores produced in vessels, although this has not yet been proved (Pascoe and Cottral 2000). However, it is important to note that, at the end of the experiment, mycelium recovery of $P$. chlamydospora below the node was significantly lower in 5 -cm pruned internodes than in 2 -cm internodes. This would confirm that the wood colonization rate of this pathogen may be lower than that of D. seriata, and that a longer pruned internode may make cane colonization by $P$. chlamydospora difficult.

Results obtained in this study based on artificial inoculations showed that pruning wound susceptibility and posterior cane colonization in grapevines may show differential features for different trunk pathogens such as D. seriata and P. chlamydospora. To the best of our knowledge, this is the first time that rates of infection at different isolation sites were assessed in artificially inoculated canes to study cane colonization of these pathogens; therefore, additional research would be needed to confirm these results in other grapegrowing regions under other climate or crop conditions. Finally, a global strategy for pruning could be optimized by pruning on dates when wound susceptibility could be lower for pathogens, and by increasing the length of the pruned internode, because longer internodes may make cane colonization by slow-growing pathogens difficult.

\section{Acknowledgments}

This study was funded by the Spanish Instituto Nacional de Investigación y Tecnología Agraria y Alimentaria (INIA), project RTA2010-00009-C03, with matching funds from the European Regional Development Fund. G. Elena was supported by INIA with a predoctoral grant. We thank V. Barnés, O. González, and O. Jurado for their technical assistance; and J. R. Úrbez-Torres (Agriculture and Agri-Food Canada, Pacific Agri-Food Research Centre) for the critical review and helpful comments on an earlier draft version.

Table 3. Analysis of variance-type statistics on the mycelium recovery percentage of Diplodia seriata and Phaeomoniella chlamydospora inoculated on grapevine pruned canes with two different pruned internode lengths

\begin{tabular}{lllrrr}
\hline Pathogen, pruned internode & Factor $^{\mathbf{a}}$ & dfN & dfD & $\boldsymbol{F}$ & $\boldsymbol{P}$ \\
\hline Diplodia seriata & & & & & \\
$2 \mathrm{~cm}$ & Date & 1 & 1 & 13.54 & 0.1689 \\
& Site & 2 & 2 & 49.42 & 0.0198 \\
& Date $\times$ site & 2 & 230 & 3.49 & 0.0322 \\
$5 \mathrm{~cm}$ & Date & 1 & 1 & 29.86 & 0.1152 \\
& Site & 3 & 3 & 17.88 & 0.0204 \\
& Date $\times$ site & 3 & 307 & 5.01 & 0.0021 \\
Phaeomoniella chlamydospora & & & & & \\
$2 \mathrm{~cm}$ & Date & 1 & 1 & 1.47 & 0.4390 \\
& Site & 2 & 2 & 41.54 & 0.0235 \\
$5 \mathrm{~cm}$ & Date $\times$ site & 2 & 230 & 0.97 & 0.3809 \\
& Date & 1 & 1 & 0.20 & 0.7309 \\
& Site & 3 & 3 & 45.10 & 0.0054 \\
& Date $\times$ site & 3 & 307 & 1.29 & 0.2778 \\
\hline
\end{tabular}

a Recovery date, recovery site, and their interaction.

Table 2. Correlation coefficients $(r)$ and significance values $(P)$ between main meteorological variables and the mycelium recovery of Diplodia seriata or Phaeomoniella chlamydospora in the wound susceptibility experiment

\begin{tabular}{|c|c|c|c|c|c|c|c|}
\hline \multirow[b]{2}{*}{ Year, pruning season } & \multirow[b]{2}{*}{ Pathogen species } & \multicolumn{2}{|c|}{ Temperature } & \multicolumn{2}{|c|}{ Relative humidity } & \multicolumn{2}{|c|}{ Accumulated rainfall } \\
\hline & & $r$ & $P$ & $r$ & $P$ & $r$ & $P$ \\
\hline \multicolumn{8}{|l|}{$2012-13$} \\
\hline \multirow[t]{2}{*}{ Early pruning } & D. seriata & 0.89 & 0.0181 & 0.67 & 0.1464 & -0.59 & 0.2178 \\
\hline & P. chlamydospora & 0.75 & 0.0882 & 0.72 & 0.1063 & 0.68 & 0.1397 \\
\hline \multirow[t]{2}{*}{ Late pruning } & D. seriata & -0.89 & 0.0167 & -0.48 & 0.3381 & -0.51 & 0.3004 \\
\hline & P. chlamydospora & -0.81 & 0.0497 & -0.36 & 0.4815 & -0.60 & 0.2108 \\
\hline \multicolumn{8}{|l|}{ 2013-14 } \\
\hline \multirow[t]{2}{*}{ Early pruning } & D. seriata & 0.30 & 0.5620 & -0.40 & 0.4261 & 0.71 & 0.1113 \\
\hline & P. chlamydospora & 0.02 & 0.9687 & -0.45 & 0.3747 & 0.49 & 0.3208 \\
\hline \multirow[t]{2}{*}{ Late pruning } & D. seriata & -0.60 & 0.2046 & -0.67 & 0.1434 & 0.47 & 0.3505 \\
\hline & P. chlamydospora & -0.32 & 0.5380 & -0.74 & 0.0900 & 0.62 & 0.1921 \\
\hline
\end{tabular}




\section{Literature Cited}

Agustí-Brisach, C., León, M., García-Jiménez, J., and Armengol, J. 2015. Detection of grapevine fungal trunk pathogens on pruning shears and evaluation of their potential for spread of infection. Plant Dis. 99:976-981.

Amponsah, N. T., Jones, E. E., Ridgway, H. J., and Jaspers, M. V. 2009. Rainwater dispersal of Botryosphaeria conidia from infected grapevines. N. Z. Plant Prot. 62:228-233.

Andreini, L., Caruso, G., Bertolla, C., Scalabrelli, G., Viti, R., and Gucci, R. 2009. Gas exchange, stem water potential and xylem flux on some grapevine cultivars affected by esca disease. S. Afr. J. Enol. Vitic. 30:142-147.

Aroca, A., Garcia-Figueres, F., Bracamonte, L., Luque, J., and Raposo, R. 2006. A survey of trunk disease pathogens within rootstocks of grapevines in Spain. Eur. J. Plant Pathol. 115:195-202.

Auger, J., Esterio, M., Ricke, G., and Pérez, I. 2004. Black dead arm and basal canker of Vitis vinifera cv. Red globe caused by Botryosphaeria obtusa in Chile. Plant Dis. 88:1286.

Baskarathevan, J., Jaspers, M. V., Jones, E. E., and Ridgway, H. J. 2013. Development of isolate-specific markers for Neofusicoccum parvum and $N$. luteum and their use to study rainwater splash dispersal in the vineyard. Plant Pathol. 62:501-509.

Bertsch, C., Ramírez-Suero, M., Magnin-Robert, M., Larignon, P., Chong, J., Abou-Mansour, E., Spagnolo, A., Clément, C., and Fontaine, F. 2013. Grapevine trunk diseases: Complex and still poorly understood. Plant Pathol. 62:243-265.

Billones-Baaijens, R., Ridgway, H. J., Jones, E. E., and Jaspers, M. V. 2015. Spatial distribution of Neofusicoccum species within a rootstock mother vine indicates potential infection pathways. Eur. J. Plant Pathol. 141:267-279.

Bostock, R. M., and Stermer, B. A. 1989. Perspectives on wound healing in resistance to pathogens. Annu. Rev. Phytopathol. 27:343-371.

Calzarano, F., and Di Marco, S. 2007. Wood discoloration and decay in grapevines with esca proper and their relationship with foliar symptoms. Phytopathol. Mediterr. 46:96-101.

Carter, M. V. 1991. The Status of Eutypa lata as a Pathogen. Phytopathol. Pap. No. 32. International Mycological Institute, Surrey, UK.

Casieri, L., Hofstetter, V., Viret, O., and Gindro, K. 2009. Fungal communities living in the wood of different cultivars of young Vitis vinifera plants. Phytopathol. Mediterr. 48:73-83.

Castillo-Pando, M., Somers, A., Green, C. D., Priest, M., and Sriskanthades, M. 2001. Fungi associated with dieback of Semillon grapevines in the Hunter Valley of New South Wales. Australas. Plant Pathol. 30:59-63.

Chapuis, L., Richard, L., and Dubos, B. 1998. Variation in susceptibility of grapevine pruning wound to infection by Eutypa lata in south-western France. Plant Pathol. 47:463-472.

Christen, D., Schönmann, S., Jermini, M., Strasser, R. J., and Défago, G. 2007. Characterization and early detection of grapevine (Vitis vinifera) stress responses to esca disease by in situ chlorophyll fluorescence and comparison with drought stress. Environ. Exp. Bot. 60:504-514.

Correia, K. C., Câmara, M. P. S., Barbosa, M. A. G., Sales, R., Jr., Agustí-Brisach, C., Gramaje, D., León, M., García-Jiménez, J., Abad-Campos, P., Armengol, J., and Michereff, S. J. 2013. Fungal trunk pathogens associated with table grape decline in Northeastern Brazil. Phytopathol. Mediterr. 52:380-387.

Crous, P. W., and Gams, W. 2000. Phaeomoniella chlamydospora gen. et comb. nov., a causal organism of Petri grapevine decline and esca. Phytopathol. Mediterr. 39:112-118.

Dal, F., Bricaud, E., Chagnon, L., and Daulny, B. 2008. Relation entre qualité de la taille et deperissement des vignes. Exemple de l'esca. Prog. Agric. Vitic. 125: 602-608.

Díaz, G. A., Prehn, D., and Latorre, B. A. 2011. First report of Cryptovalsa ampelina and Eutypella leprosa associated with grapevine trunk diseases in Chile. Plant Dis. 95:490.

Doster, M. A., and Bostock, R. M. 1988. Effect of low temperature on resistance to almond trees to Phytophthora pruning wound cankers in relation to lignin and suberin formation in wounded bark tissue. Phytopathology 78:478-483.

Elena, G., Sosnowski, M. R., Ayres, M. R., Lecomte, P., Benetreau, C., GarciaFigueres, F., and Luque, J. 2015. Effect of the inoculum dose of three grapevine trunk pathogens on the infection of artificially inoculated pruning wounds. Phytopathol. Mediterr. 54:345-354.

Eskalen, A., Feliciano, A. J., and Gubler, W. A. 2007. Susceptibility of grapevine pruning wounds and symptom development in response to infection by Phaeoacremonium aleophilum and Phaeomoniella chlamydospora. Plant Dis. 91:1100-1104.

Eskalen, A., and Gubler, W. D. 2001. Association of spores of Phaeomoniella chlamydospora, Phaeoacremonium inflatipes, and Pm. aleophilum with grapevine cordons in California. Phytopathol. Mediterr. 40:429-432.

Fischer, M. 2002. A new wood-decaying basidiomycete species associated with esca of grapevine: Fomitiporia mediterranea (Hymenochaetales). Mycol. Prog. 1:315-324.

Galet, P. 2000. Précis de Viticulture, 7th ed. JF Impression, St. Jean de Vedas, France.

Giménez-Jaime, A., Aroca, A., Raposo, R., García-Jiménez, J., and Armengol, J. 2006. Occurrence of fungal pathogens associated with grapevine nurseries and the decline of young vines in Spain. J. Phytopathol. 154:598-602.

González, V., and Tello, M. L. 2011. The endophytic mycota associated with Vitis vinifera in central Spain. Fungal Divers. 47:29-42.
Gramaje, D., Mostert, L., Groenewald, J. Z., and Crous, P. W. 2015. Phaeoacremonium: From esca disease to phaeohyphomycosis. Fungal Biol. 119:759-783.

Gubler, W. D., Eskalen, A., Feliciano, A. J., and Khan, A. 2001. Susceptibility of grapevine pruning wounds to Phaeomoniella chlamydospora and Phaeoacremonium spp. Phytopathol. Mediterr. 40:S482-S483.

Gubler, W. D., Rolshausen, P. E., Trouillas, F. P., Úrbez-Torres, J. R., Voegel, T., Leavitt, G. M., and Weber, E. A. 2005. Grapevine trunk diseases in California. Practical Winery Vineyard January-February:6-25.

Halleen, F., Mostert, L., and Crous, P. 2007. Pathogenicity testing of lesser-known vascular fungi of grapevines. Australas. Plant Pathol. 36:277-285.

Halleen, F., van Niekerk, J., Mostert, L., Fourie, P., and Crous, P. 2005. Trunk disease pathogens associated with apparently healthy nursery grapevines. Wineland July:79-81.

Jordan, S. A., and Schilder, A. M. C. 2007. Characterization of Eutypella vitis, a potential pathogen of grapevines. Phytopathol. Mediterr. 46:105.

Kuntzmann, P., Villaume, S., and Bertsch, C. 2009. Conidia dispersal of Diplodia species in a French vineyard. Phytopathol. Mediterr. 48:150-154.

Lafon, R. 1921. Modifications à apporter à la taille de la vigne dans les Charentes. Imp. Roumégous et Dahan, Montpellier, France.

Larignon, P., and Dubos, B. 2000. Preliminary studies on the biology of Phaeoacremonium. Phytopathol. Mediterr. 39:184-189.

Larignon, P., Fulchie, R. N., Cere, L., and Dubos, B. 2001. Observation on Black Dead Arm in French vineyards. Phytopathol. Mediterr. 40:S336-S342.

Lecomte, P., and Bailey, D. J. 2011. Studies on the infestation by Eutypa lata of grapevine spring wounds. Vitis 50:35-41.

Lecomte, P., Darrieutort, G., Liminana, J. M., Comont, G., Muruamendiaraz, A., Legorburu, F. J., Choueiri, E., Jreijiri, F., El Amil, R., and Fermaud, M. 2012. New insights into esca of grapevine: The development of foliar symptoms and their association with xylem discoloration. Plant Dis. 96:924-934.

Linaldeddu, B. T., Deidda, A., Scanu, B., Franceschini, A., Serra, S., BerrafTebbal, A., Zouaoui Boutiti, M., Ben Jamâa, M. L., and Phillips, A. J. L. 2014. Diversity of Botryosphaeriaceae species associated with grapevine and other woody hosts in Italy, Algeria and Tunisia, with descriptions of Lasiodiplodia exigua and Lasiodiplodia mediterranea sp. nov. Fungal Divers. 71:201-214.

Luque, J., Elena, G., Garcia-Figueres, F., Reyes, J., Barrios, G., and Legorburu, F. J. 2014. Natural infections of pruning wounds by fungal trunk pathogens in mature grapevines in Catalonia (Northeast Spain). Aust. J. Grape Wine Res. 20:134-143.

Luque, J., Garcia-Figueres, F., Legorburu, F. J., Muruamendiara, A., Armengol, J., and Trouillas, F. P. 2012. Species of Diatrypaceae associated with grapevine trunk diseases in Eastern Spain. Phytopathol. Mediterr. 51:528-540.

Luque, J., Martos, S., Aroca, A., Raposo, R., and Garcia-Figueres, F. 2009. Symptoms and fungi associated with declining mature grapevine plants in Northeast Spain. J. Plant Pathol. 91:381-390.

Maher, N., Piot, J., Bastien, S., Vallance, J., Rey, P., and Guérin-Dubrana, L. 2012. Wood necrosis in esca-affected vines: Types, relationships and possible links with foliar symptom expression. J. Int. Sci. Vigne Vin 46:15-27.

Michailides, T. J., and Morgan, D. P. 1993. Spore release by Botryosphaeria dothidea in pistachio orchards and disease control by altering the trajectory angle of sprinklers. Phytopathology 83:145-152.

Mohammadi, H., Gramaje, D., Banihashemi, Z., and Armengol, J. 2013. Characterization of Diplodia seriata and Neofusicoccum parvum associated with grapevine decline in Iran. J. Agric. Sci. Technol. 15:603-616.

Moller, W. S., and Kasimatis, A. N. 1978. Dieback of grapevines caused by Eutypa armeniacae. Plant Dis. Rep. 62:254-258.

Molyneux, R. J., Mahoney, N., Bayman, P., Wong, R. Y., Meyer, K., and Irelan, N. 2002. Eutypa dieback in grapevines: Differential production of acetylenic phenol metabolites by strains of Eutypa lata. J. Agric. Food Chem. 50: 1393-1399.

Mugnai, L., Graniti, A., and Surico, G. 1999. Esca (black measles) and brown wood-streaking: Two old and elusive diseases of grapevines. Plant Dis. 83: 404-418.

Munkvold, G. P., and Marois, J. J. 1995. Factors associated with variation in susceptibility of grapevine pruning wounds to infection by Eutypa lata. Phytopathology 85:249-256.

Paillassa, E. 1992. L'eutypiose de la vigne (Eutypa lata (Pers.:Fr.) Tul.)—Aspects épidémiologiques et leur application à la mise au point d'une méthode d'évaluation des fongicides in vivo. Ph.D. dissertation, Bordeaux II University, Bordeaux, France.

Pascoe, I., and Cottral, E. 2000. Developments in grapevine trunk diseases research in Australia. Phytopathol. Mediterr. 39:68-75.

Pearson, R. C. 1980. Discharge of ascospores of Eutypa armeniacae in New York. Plant Dis. 64:171-174.

Petzoldt, C. H., Moller, W. J., and Sall, M. A. 1981. Eutypa dieback of grapevine: Seasonal differences in infection and duration of susceptibility of pruning wounds. Plant Dis. 71:540-543.

Petzoldt, C. H., Sall, M. A., and Moller, W. J. 1983. Factors determining the relative number of ascospores released by Eutypa armeniacae in California. Plant Dis. 67:857-860.

Phillips, A. J. L. 2002. Botryosphaeria species associated with diseases of grapevines in Portugal. Phytopathol. Mediterr. 41:3-18.

Phillips, A. J. L., Crous, P. W., and Alves, A. 2007. Diplodia seriata, the anamorph of "Botryosphaeria" obtusa. Fungal Divers. 25:141-155. 
Pitt, W. M., Huang, R., Steel, C. C., and Savocchia, S. 2013a. Pathogenicity and epidemiology of Botryosphaeriaceae species isolated from grapevines in Australia. Australas. Plant Pathol. 42:573-582.

Pitt, W. M., Úrbez-Torres, J. R., and Trouillas, F. P. 2013b. Dothiorella vidmadera, a novel species from grapevines in Australia and notes on Spencermartinsia. Fungal Divers. 61:209-219.

Ramos, D. E., Moller, W. J., and English, H. 1975. Production and dispersal of ascospores of Eutypa armeniacae in California. Phytopathology 65:1364-1371.

Renaud, J.-M., Tsoupras, G., Stoeckli-Evans, H., and Tabacchi, R. 1989. A novel allenic epoxycyclohexane and related compounds from Eutypa lata (Pers.:Fr.) Tul. Helv. Chim. Acta 72:1262-1267.

Rovesti, L., and Montermini, A. 1987. Un deperimento della vite causato da Sphaeropsis malorum diffuso in provincia di Reggio Emilia. Inf. Fitopatol. 37:59-61.

Savocchia, S., Steel, C. C., Stodart, B. J., and Somers, A. 2007. Pathogenicity of Botryosphaeria species isolated from declining grapevines in sub tropical regions of Eastern Australia. Vitis 46:27-32.

Serra, S., Mannoni, M. A., and Ligios, V. 2008. Studies on the susceptibility of pruning wounds to infection by fungi involved in grapevine wood diseases in Italy. Phytopathol. Mediterr. 47:234-246.

Shigo, A. 1984. Compartmentalization: A conceptual framework for understanding how trees grow and defend themselves. Annu. Rev. Phytopathol. 22:189-214.

Surico, G., Mugnai, L., and Marchi, G. 2006. Older and more recent observations on esca: A critical overview. Phytopathol. Mediterr. 45:68-86.

Tello, M. L., Gramaje, D., Gómez, A., Abad-Campos, P., and Armengol, J. 2010. Analysis of phenotypic and molecular diversity of Phaeomoniella chlamydospora isolates in Spain. J. Plant Pathol. 92:195-203.

Tey-Rulh, P., Phillippe, I., Renaud, J. M., Tsoupras, G., de Angelis, P., Fallot, J., and Tabacchi, R. 1991. Eutypine, a phytotoxin produced by Eutypa lata, the causal agent of dying-arm disease of grapevine. Phytochemistry 30:471-473.

Trese, A. T., Burton, C. L., and Ramsdell, D. C. 1980. Eutypa armeniacae in Michigan vineyards: Ascospore production and survival, host infection, and fungal growth at low temperatures. Phytopathology 70:788-793.

Troccoli, L., Calamassi, R., Mori, B., Mugnai, L., and Surico, G. 2001. Phaeomoniella chlamydospora-grapevine interaction: Histochemical reactions to fungal infection. Phytopathol. Mediterr. 40:S400-S406.

Trouillas, F. P., and Gubler, W. D. 2009. The status of Eutypa lata in California. Phytopathol. Mediterr. 48:161-162.

Trouillas, F. P., and Gubler, W. D. 2010. Pathogenicity of Diatrypaceae species in grapevines in California. Plant Dis. 94:867-872.

Trouillas, F. P., Pitt, W. M., Sosnowski, M. R., Huang, R., Peduto, F., Loschiavo, A., Savocchia, S., Scott, E. S., and Gubler, W. D. 2011. Taxonomy and DNA phylogeny of Diatrypaceae associated with Vitis vinifera and other woody plants in Australia. Fungal Divers. 49:203-223.
Trouillas, F. P., Úrbez-Torres, J. R., and Gubler, W. D. 2010. Diversity of diatrypaceous fungi associated with grapevine canker diseases in California. Mycologia 102:319-336.

Úrbez-Torres, J. R. 2011. The status of Botryosphaeriaceae species infecting grapevines. Phytopathol. Mediterr. 50:S5-S45.

Úrbez-Torres, J. R., and Gubler, W. D. 2009. Pathogenicity of Botryosphaeriaceae species isolated from grapevine cankers in California. Plant Dis. 93:584-592.

Úrbez-Torres, J. R., and Gubler, W. D. 2011. Susceptibility of grapevine pruning wounds to infection by Lasiodiplodia theobromae and Neofusicoccum parvum. Plant Pathol. 60:261-270.

Úrbez-Torres, J. R., Adams, P., Kamas, J., and Gubler, W. D. 2009. Identification, incidence, and pathogenicity of fungal species associated with grapevine dieback in Texas. Am. J. Enol. Vitic. 60:497-507.

Úrbez-Torres, J. R., Battany, M., Bettiga, L. J., Gispert, C., McGourty, G., Roncoroni, J., Smith, R. J., Verdegaal, P., and Gubler, W. D. 2010 Botryosphaeriaceae species spore-trapping studies in California vineyards. Plant Dis. 94:717-724.

Úrbez-Torres, J. R., Leavitt, G. M., Guerrero, J. C., Guevara, J., and Gubler, W. D 2008. Identification and pathogenicity of Lasiodiplodia theobromae and Diplodia seriata, the causal agents of Bot canker disease of grapevines in Mexico. Plant Dis. 92:519-529.

Úrbez-Torres, J. R., Leavitt, G. M., Voegel, T. M., and Gubler, W. D. 2006. Identification and distribution of Botryosphaeria spp. associated with grapevine cankers in California. Plant Dis. 90:1490-1503.

Úrbez-Torres, J. R., Peduto, F., Striegler, R. K., Urrea-Romero, K. E., Rupe, J. C. Cartwright, R. D., and Gubler, W. D. 2012. Characterization of fungal pathogens associated with grapevine trunk diseases in Arkansas and Missouri. Plant Dis. 52: 169-189.

van Niekerk, J. M., Calitz, F. J., Halleen, F., and Fourie, P. H. 2010. Temporal spore dispersal patterns of grapevine trunk pathogens in South Africa. Eur. J. Plant Pathol. 127:375-390.

van Niekerk, J. M., Crous, P. W., Groenewald, J. Z., Fourie, P. H., and Halleen, F. 2004. DNA phylogeny, morphology and pathogenicity of Botryosphaeria species on grapevines. Mycologia 96:781-798.

van Niekerk, J. M., Halleen, F., and Fourie, P. H. 2011. Temporal susceptibility of grapevine pruning wounds to trunk pathogen infection in South African grapevines. Phytopathol. Mediterr. 50:S139-S150.

Whiting, E. C., Khan, A., and Gubler, W. D. 2001. Effect of temperature and water potential on survival and mycelial growth of Phaeomoniella chlamydospora and Phaeoacremonium spp. Plant Dis. 85:195-201.

Yan, J.-Y., Xie, Y., Zhang, W., Wang, Y., Liu, J.-K., Hyde, K., Seem, R., Zhang, G.-Z., Wang, Z.-Y., Yao, S.-W., Bai, X.-J., Dissanayake, A., Peng, Y.-L., and $\mathrm{Li}, \mathrm{X} . \mathrm{-H} .2013$. Species of Botryosphaeriaceae involved in grapevine dieback in China. Fungal Divers. 61:221-236. 